\title{
A Critical Analysis of the New Equal Pay Provisions Relating to Atypical Employees in Sections 198A-198D of the LRA: Important Lessons from the United Kingdom
}

\section{P.E.R}

Pioneer in peer-reviewed, open access online law publications

Author

Shamier Ebrahim

Affiliation

University of South Africa

Email ebrahs1@unisa.ac.za

Date published

19 December 2017

Editor Prof O Fuo

How to cite this article

Ebrahim S "A Critical Analysis of the New Equal Pay Provisions Relating to Atypical Employees in Sections 198A-198D of the LRA: Important Lessons from the United Kingdom" PER / PELJ 2017(20) DOI

http://dx.doi.org/10.17159/1727-

3781/2017/v20i0a1956

\section{Copyright}

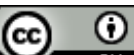

DOI http://dx.doi.org/10.17159/17273781/2017/v20i0a1956

\section{Abstract}

The Employment Equity Act 55 of 1998 (EEA) is the main piece of legislation which seeks to achieve equity in the workplace by redressing unfair discrimination. Unequal pay for equal work and work of equal value are specific forms of discrimination which are dealt with in the EEA. The EEA provisions dealing with pay discrimination applies to all employees in the workplace which includes atypical employees. An employee experiencing pay discrimination in the workplace would thus use the EEA to institute an equal pay claim. This, however, has changed since the introduction of sections 198A-198D of the Labour Relations Act 66 of 1995 (LRA) which provides equal pay protection for atypical employees earning below the threshold of R205 433.30 and subject to certain other conditions. Sections 198A-198D of the LRA only deals with equal pay for the same or similar work. The sections do not deal with equal pay for work of equal value. This equal pay protection in the LRA is unique as the redress of unfair discrimination is not one of the purposes of the LRA.

The purpose of this article is to analyse the equal pay provisions as set out in sections 198A-198D of the LRA in order to ascertain the ambit of the protection offered by the sections, the limitations thereof and the dispute resolution procedure which should be followed. A brief comparative study with the law regulating equal pay for atypical employees in the United Kingdom will be undertaken in order to learn lessons for the equal pay legal framework in the LRA. International labour law will also be referred to.

\section{Keywords}

Equal pay; Labour Relations Act; equal pay for atypical employees; atypical employment; sections 198A-198D of the Labour Relations Act; Agency Workers Regulations 2010; Fixedterm Employees (Prevention of Less Favourable Treatment) Regulations 2002; Part-time Workers (Prevention of Less Favourable Treatment) Regulations 2000; LRA; EEA. 


\section{Introduction}

The Employment Equity Act (EEA) is the main piece of legislation which seeks to achieve equity in the workplace by redressing unfair discrimination. Unequal pay for equal work and work of equal value are specific forms of discrimination which are dealt with in the EEA. The EEA provisions dealing with pay discrimination applies to all employees in the workplace which includes atypical employees. An employee experiencing pay discrimination in the workplace would thus use the EEA to institute an equal pay claim. This, however, has changed since the introduction of sections 198A-198D of the Labour Relations Act (LRA) which provides equal pay protection for atypical employees earning below the threshold of R205 433.30 and subject to certain other conditions. Sections 198A-198D of the LRA only deals with equal pay for the same or similar work. The sections do not deal with equal pay for work of equal value. This equal pay protection in the LRA is unique as the redress of unfair discrimination is not one of the purposes of the LRA. $^{3}$

The purpose of this article is to analyse the equal pay provisions as set out in sections 198A-198D of the LRA in order to ascertain the ambit of the protection offered by the sections, the limitations thereof and the dispute resolution procedure which should be followed. A brief comparative study with the law regulating equal pay for atypical employees in the United Kingdom will be undertaken in order to learn lessons for the equal pay legal framework in the LRA. International labour law will also be referred to.

\footnotetext{
Shamier Ebrahim. LLB (NMMU); LLM Labour Law (cum laude) (Unisa), Senior Lecturer, Department of Mercantile Law, University of South Africa. Advocate of the High Court of South Africa. Associate Member of the Pretoria Society of Advocates (Pretoria Bar). E-mail: ebrahs1@unisa.ac.za. This article is based on a paper presented at the $4^{\text {th }}$ Academic International Conference on Interdisciplinary Legal Studies, Martin Conference Centre, Boston USA, 21 November 2016 under the title "The Emergence of the New Equal Pay Provisions in the Labour Relations Act 66 of 1995: Better Protection for Atypical Employees in South Africa?". The author would like to thank the Executive Committee of the College of Law and the College Research and Innovation Committee of the University of South Africa for funding the conference attendance in the USA and for providing funds for the author to conduct research at the Harvard Law School Library, Cambridge, USA.

Employment Equity Act 55 of 1998 (EEA).

Labour Relations Act 66 of 1995 (LRA).

It is, however, apposite to note that the LRA treats a dismissal as being automatically unfair in terms of $s$ 187(1)(f) of the LRA if the reason for the dismissal is that the employer unfairly discriminated against the employee.
} 


\section{An analysis of sections 198A-198D of the LRA regarding equal pay}

Prior to the insertion of sections 198A-198D in the LRA, academic writers have commented on the lack of protection relating to atypical employees. Van Eck has stated that employees placed by a temporary employment service do not receive the same wages and other conditions of service as the permanent employees of the client. He called for legislative reforms dealing with the prohibition against unfair discrimination associated with different wages and conditions of service for full-time employees and those placed by a temporary employment service. ${ }^{4}$ Fourie has submitted that parttime employees in South Africa should be able to rely on the principle of equal pay for equal work until specific legislation is introduced. ${ }^{5}$ Theron has argued that section 27(1) of the EEA which requires a designated employer to report on remuneration and benefits received in each occupational category and level of that employer's workforce does not assist workers placed by a temporary employment service as the workers are regarded as a discrete workforce and the obligation on the designated employer to take measures to address disproportionate income differentials is of no assistance to them. He further argued that disproportionate income differentials between workers placed by a temporary employment service and workers in standard employment undermines the objectives of equity and should be legislated against whether by amendment to the EEA or otherwise. $^{6}$ Benjamin notes from the unpublished CCMA Report on Difficulties with Labour Brokers of 2009 that there is usually inequity between workers placed by a temporary employment service and permanent employees regarding equitable pay and benefits, inter alia. ${ }^{7}$

Sections 198A-198D of the LRA sets out certain protection to atypical employees which includes amongst others, equal pay protection. Only the equal pay provisions will be analysed. Section 198A of the LRA applies to employees who earn below the threshold ${ }^{8}$ and who are employed by a temporary employment service. A "temporary service" is defined as work for a client by an employee of the temporary employment service for a period not exceeding three months, as a substitute for an employee of the client who is temporarily absent, or in a category of work and for any period of time which is determined to be a temporary employment service in terms of a collective agreement concluded in a bargaining council, a sectoral determination, or notice published by the Minister in terms of subsections

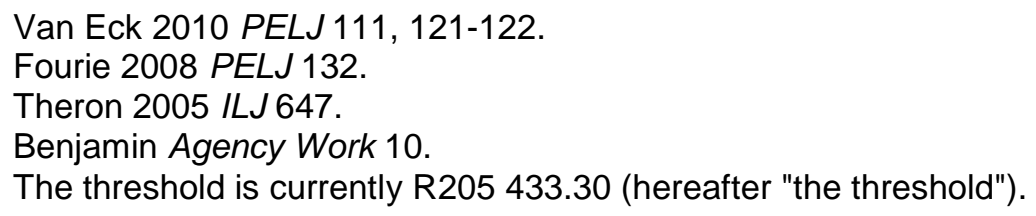


(6)-(8). ${ }^{9}$ The section then goes on to state that an employee who performs a temporary service as defined above for the client is the employee of the temporary employment service and not the client. It further states that an employee who performs a service that falls outside the ambit of a temporary service as defined is deemed to be the employee of the client and the client is deemed to be the employer and the employee is employed on an indefinite basis by the client subject to section 198B of the LRA. ${ }^{10}$ Section $198 \mathrm{~A}(4)$ of the LRA protects an employee against an attempt by the temporary employment service or the client to circumvent section $198 \mathrm{~A}(3)$ (b) of the LRA which regards the employee as the employee of the client and regards the employment as indefinite subject to section 198B of the LRA by providing that the termination of the employee's service for the purpose of avoiding the operation of section 198(A)(3)(b) of the LRA or because the employee exercised a right in terms of the LRA, is a dismissal.

The equal pay provision is contained in section $198 \mathrm{~A}(5)$ of the LRA and reads as follows:

An employee deemed to be an employee of the client in terms of subsection (3)(b) must be treated on the whole not less favourably than an employee of the client performing the same or similar work, unless there is a justifiable reason for different treatment.

This section will only apply to a case where the employee is deemed to be an employee of the client. It will further only apply in a case involving the same or similar work. The phrase "must be treated on the whole not less favourably" is a departure from a normal equal pay for the same or similar work claim in terms of the EEA which requires the pay to be equal and not on the whole not less favourable. ${ }^{11}$ The term "on the whole not less favourably" while foreign to equal pay claims in terms of the EEA is not foreign to the LRA as it is used in the context of a transfer of a business as a going concern as follows:

\section{The new employer complies with subsection (2) if that employer employs transferred employees on terms and conditions that are on the whole not less favourable to the employees than those on which they were employed by the old employer. ${ }^{12}$}

The phrase "on the whole not less favourably" is not defined in the LRA. Grogan states that no test has been formulated to determine the extent to which an employer may amend the terms and conditions of transferred employees and still comply with section 197(3)(a) of the LRA. He further

\footnotetext{
9 Section $198 \mathrm{~A}(1)(\mathrm{c})$ of the LRA.

10 Section 198A(3)(a)-(b) of the LRA.

11 Emphasis added.

12 Section 197(3)(a) of the LRA, emphasis added.
} 
states that the changes contemplated in section 197(3)(a) of the LRA must fall short of changes to fundamental terms of an employee's contract. ${ }^{13}$ Clause 38 of the Memorandum of Objects of the Labour Relations Amendment Bill, $2012^{14}$ (hereafter "the Memo") provides the following example of what would constitute treatment that is "on the whole not less favourably" in terms of section 198A(5) of the LRA:

This means, for example, that if an employee is procured by a temporary employment service for a client for three months, but is kept on after the expiry of the three-month period, then that employee must, unless there is a justifiable reason for different treatment, be paid the same wages and benefits as the client's other employees who are performing the same or similar work.

This example in the Memo is important as it demonstrates the intended meaning of the phrase "on the whole not less favourably" in terms of section 198A(5) of the LRA. According to the Memo the phrase means that an employee who is deemed to be an employee of the client must be paid the same wages and given the same benefits as the client's other employees. This would mean that the employee must be treated the same as the client's other employees. Seen in this light, the use of the phrase "on the whole not less favourably" in section 198A(5) of the LRA leads to confusion as according to the Memo it is intended to bring about a result that is the same. The Labour Courts have used explanatory memorandums to Labour Relations Bills to assist them in determining the meaning to be accorded to certain provisions of the LRA resulting from the Bills. ${ }^{15}$ The information from the explanatory memorandums is important as it forms part of the interpretative process to interpreting the LRA.

Section 198B of the LRA applies to fixed-term contract employees earning below the threshold. This section does not apply to (a) employees who earn more than the threshold; and (b) an employee employed in terms of a fixedterm contract which is permitted by statute, sectoral determination or collective agreement; and (c) an employer who employs less than ten employees or employs less than fifty employees and whose business has been in operation for less than two years, unless the employer conducts more than one business or the business was formed by the division or dissolution for any reason of an existing business. ${ }^{16}$ An employer may only employ an employee on a fixed-term contract or successive fixed-term contracts for longer than three months if the nature of the work is of a limited

13 Grogan Workplace Law 301-302.

14 DoL 2013 http://www.labour.gov.za/DOL/downloads/legislation/bills/proposedamendment-bills//raamendmentbill2013.pdf.

15 See Shoprite Checkers (Pty) Ltd v Ramdaw 20013 SA 68 (LC) paras 59-60; and National Union of Metalworkers of South Africa v Driveline 20004 SA 645 (LAC) paras 79-80.

16 Section 198B(2)(a)-(c) of the LRA. 
or definite duration or the employer can advance a justifiable reason for fixing the term of the contract. ${ }^{17}$ If an employer employs an employee in contravention of this section then the fixed-term contract or the renewal of the contract is deemed to be for an indefinite duration. Section 198B(8)(a) of the LRA contains the equal pay provision and reads as follows:

An employee employed in terms of a fixed term contract for longer than three months must not be treated less favourably than an employee employed on a permanent basis performing the same or similar work, unless there is a justifiable reason for different treatment.

This section requires that the employee must not be treated less favourably than a permanent employee performing the same or similar work unless there is a justifiable reason for doing so. Clause 38 of the Memo refers to fixed-term employees being treated "on the whole not less favourably" instead of "not less favourably" as set out in the section. The clause refers to the phrase "on the whole not less favourably" in the context of fixed-term contract employees as follows:

An employee employed on a fixed term contract for more than three months
(or any other period determined by a sectoral determination or collective
agreement concluded at a bargaining council) must be treated on the whole
not less favourably than an employee on an indefinite contract performing the
same or similar work, unless there is a justifiable reason for treating the
employee differently. What may constitute a justifiable reason for this purpose
is dealt with in section 198D. (emphasis added)

This anomaly adds to the difficulty regarding the meaning to be accorded to the phrases "on the whole not less favourably" and "not less favourably". The Explanatory Memorandum to the Bill of an Act that is passed provides an aid of interpretation with which to interpret the Act. In this case the Memo causes confusion rather than providing assistance in the form of understanding the interpretation to be accorded to the relevant sections in the Act. A brief analysis of foreign law relating to equal pay for atypical employees is sorely needed in order to understand how foreign law seeks to achieve equal pay for atypical employees. It is also important to do an

17 Section 198B(3)(a)-(b) of the LRA. Section 198B(4) of the LRA sets out the following list of reasons which would amount to a justifiable reason as contemplated in section $198 \mathrm{~B}(3)(\mathrm{b})$ of the LRA: "(a) is replacing another employee who is temporarily absent from work; (b) is employed on account of a temporary increase in the volume of work which is not expected to endure beyond 12 months; (c) is a student or recent graduate who is employed for the purpose of being trained or gaining work experience in order to enter a job or profession; (d) is employed to work exclusively on a specific project that has a limited or defined duration; (e) is a noncitizen who has been granted a work permit for a defined period; $(f)$ is employed to perform seasonal work; $(\mathrm{g})$ is employed for the purpose of an official public works scheme or similar public job creation scheme; $(h)$ is employed in a position which is funded by an external source for a limited period; or (i) has reached the normal or agreed retirement age applicable in the employer's business". 
analysis of foreign law in order to learn lessons for the atypical legal framework in the LRA. To this end, an analysis of the law regulating equal pay for atypical employees in the United Kingdom will be undertaken in paras 4.1-4.3 below.

Section 198C of the LRA deals with part-time employees who earn below the threshold. A part-time employee is defined as an employee who is remunerated wholly or partly by reference to the time that the employee works and who works less hours than a comparable full-time employee. ${ }^{18}$ This section does not apply: (a) to employees who earn more than the threshold; (b) to employees who ordinarily work less than twenty fours a month for an employer; (c) during the first three months of continuous employment with an employer; and (d) to an employer who employs less than ten employees or who employs less than fifty employees and whose business has been in operation for less than two years unless the employer conducts more than one business or the business was formed by the division or dissolution for any reason of an existing business. ${ }^{19}$ The equal pay provision is set out in section $198 \mathrm{C}(3)(\mathrm{a})$ of the LRA which reads as follows:

(3) Taking into account the working hours of a part-time employee, irrespective of when the part-time employee was employed, an employer must-

(a) treat a part-time employee on the whole not less favourably than a comparable fulltime employee doing the same or similar work, unless there is a justifiable reason for different treatment.

This section like section $198 \mathrm{~A}(5)$ of the LRA also refers to the phrase "on the whole not less favourably". Section 198C(6) of the LRA sets out the requirements to choose a comparable full-time employee. The part-time employee must choose a full-time employee employed by the employer on the same type of employment relationship who performs the same or similar work in the same workplace or if there is no comparable full-time employee in the same workplace, then a comparable full-time employee employed by the employer in any other workplace. ${ }^{20}$ The comparable full-time employee must be in the same workplace as the part-time employee except where there is no comparable full-time employee in the same workplace then the

18 Section $198 \mathrm{C}(1)$ (a) of the LRA. S 198(1)(b)(i)-(ii) of the LRA defines a comparable full-time employee as follows: "(i) is an employee who is remunerated wholly or partly by reference to the time that the employee works and who is identifiable as a fulltime employee in terms of the custom and practice of the employer of that employee; and (ii) does not include a fulltime employee whose hours of work are temporarily reduced for operational requirements as a result of an agreement".

19 Section $198 \mathrm{C}(2)(\mathrm{a})-(\mathrm{d})$ of the LRA.

20 Section $198 \mathrm{C}(6)(\mathrm{a})-(\mathrm{b})$ of the LRA. 
employee may identify a comparable full-time employee who is employed by the employer in any other workplace.

Sections 198A, 198B and 198C of the LRA state that an employee must be treated "on the whole not less favourably" and "not less favourably" unless there is a justifiable reason for the different treatment. To this end, section $198 D(2)$ of the LRA provides that a justifiable reason would include that the different treatment is as a result of the application of a system that takes into account the following: (a) seniority, experience, length of service; (b) merit; (c) the quality or quantity of work performed; or (d) any other criteria of a similar nature; and such reason is not prohibited by section 6(1) of the EEA. ${ }^{21}$ Sections $198 \mathrm{~A}(5), 198 \mathrm{~B}(8)(\mathrm{a})$ and $198 \mathrm{C}(3)(\mathrm{a})$ of the LRA dealing with equal pay for temporary service employees, fixed-term contract employees and part-time employees do not require the respective employees to prove unfair discrimination in order to succeed with an equal pay claim in terms of either section. The sections further do not require an employee to prove a prima facie case of discrimination before the burden will shift to the employer to prove that the discrimination is not unfair as there is a justifiable reason for the differentiation. Section $198 \mathrm{D}(2)$ provides examples of what would amount to a justifiable reason and requires that such reason should not be prohibited by section 6(1) of the EEA. The interpretation one gains from this section is that the employer will have to prove that the ground is not prohibited by section 6(1) of the EEA as it is the one who would have to advance a justifiable reason for the differential treatment in order to successfully defend an equal pay claim in terms of sections $198 \mathrm{~A}(5), 198 \mathrm{~B}(8)(\mathrm{a})$ and $198 \mathrm{C}(3)(\mathrm{a})$ of the LRA, respectively. This would mean that an employee's burden of proof will be limited to the following:

a) In terms of section $198 \mathrm{~A}(5)$ of the LRA an employee will have to prove the following: (a) that he/she is not excluded from the protection of the section; (b) that he/she is deemed to be an employee of the client in terms of subsection 3(b); and (c) that he/she performs the same or similar work as an employee of the client but is treated on the whole less favourably.

b) In terms of section 198B(8)(a) of the LRA an employee will have to prove the following: (a) that he/she is not excluded from the protection of the section; (b) that he/she is employed on a fixed-term contract for longer than three months; and (c) that he/she performs the same or similar work as a permanent employee of the employer but is treated less favourably.

21 Section $198 \mathrm{D}(2)(\mathrm{a})-(\mathrm{d})$ of the LRA. 
c) In terms of section $198 \mathrm{C}(3)$ (a) of the LRA read with section $198 \mathrm{C}(6)$ of the LRA an employee will have to prove the following: (a) that he/she is not excluded from the protection of the section; (b) that he/she is employed as a part-time employee; and (c) that he/she performs the same or similar work as a comparable full-time employee of the employer but is treated on the whole less favourably.

Once the employee has discharged the onus as set out above, then the onus will shift to the employer to prove that there is a justifiable reason for the different treatment and that the reason is not prohibited by section 6(1) of the EEA. This is a marked difference as opposed to how an equal pay claim would be dealt with in terms of the EEA. In terms of the EEA a claimant would have to prove unfair discrimination on a listed ground or unlisted ground (arbitrary ground). Section 198D(2) of the LRA does not require the employee to prove that she was unfairly discriminated against by the employer as it merely states that the justifiable reason advanced must not be prohibited by section 6(1) of the EEA which states the following:

\begin{abstract}
No person may unfairly discriminate, directly or indirectly, against an employee, in any employment policy or practice, on one or more grounds, including race, gender, sex, pregnancy, marital status, family responsibility, ethnic or social origin, colour, sexual orientation, age, disability, religion, HIV status, conscience, belief, political opinion, culture, language, birth or on any other arbitrary ground.
\end{abstract}

This would mean that the employer will have to prove that the justifiable reason is not prohibited in terms of section 6(1) of the EEA as it is the party that will advance reasons for the different treatment. This is confusing as it is a departure from the EEA with regard to proving an unfair discrimination claim. Sections $198 \mathrm{~A}-198 \mathrm{C}$ of the LRA thus contains a novel equal pay legal framework which does not require an employee to prove that she is paid less as a result of the employer discriminating against her unfairly. It is the employer who bears the onus to prove that the differential treatment is based on a justifiable reason and such reason is not unfairly discriminatory.

Section $198 \mathrm{D}(1)$ of the LRA states that any dispute arising from the interpretation or application of sections 198A, 198B and 198C may be referred to the CCMA or bargaining council for conciliation and if not resolved, to arbitration. A party to a dispute, except a dismissal dispute in terms of section 198A(4) of the LRA, may refer the dispute in writing to the CCMA or bargaining council within six months of the act or omission. The party referring the dispute must satisfy the CCMA that a copy of the referral has been served on every party to the dispute. If the dispute remains unresolved after conciliation then a party to the dispute may refer it to the 
CCMA within 90 days. The CCMA may condone non-compliance with the time-limits on good cause shown. ${ }^{22}$

\section{The need for international and comparative labour law when interpreting the LRA}

Section 3 of the LRA which sets out the approach which should be adopted when interpreting the LRA states that the Act must be interpreted to give effect to its primary objects; and must comply with both the Constitution ${ }^{23}$ and the public international law obligations of the Republic. ${ }^{24}$ The LRA gives effect to section 23(1) of the Constitution which provides for the right to fair labour practices. ${ }^{25}$ This means that the provisions of the LRA must be interpreted to give effect to section 23(1) of the Constitution. In NEHAWU v University of Cape Town ${ }^{26}$ the CC held that the concept of fair labour practice as enshrined in section 23(1) of the Constitution is incapable of precise definition and it is not desirable to define this concept. The CC further held that the Labour Courts' are responsible for the interpretation and application of the LRA and should seek guidance from domestic and international experience in this regard. The CC went on to state that international experience is reflected in both the Conventions and Recommendations of the International Labour Organisation as well as related foreign instruments. ${ }^{27}$ Section 233 of the Constitution provides that the courts' must prefer any reasonable interpretation of any legislation that is consistent with international law over any alternative interpretation that is inconsistent with same.

It is clear from the above that international law is important when interpreting the provisions of the LRA and it is submitted that the use of international law is indispensable when the provisions to be interpreted are novel and have not been dealt with before as is the case with the new equal pay provisions in sections $198 \mathrm{~A}-198 \mathrm{D}$ of the LRA.

The main sources of international labour law are to be found in the Conventions and Recommendations of the ILO. Regional Instruments such as Instruments of the European Union also constitute a source of

\footnotetext{
22 Section 198D(3)-(6) of the LRA.

23 Constitution of the Republic of South Africa, 1996 (the Constitution).

24 Section 3(a)-(b) of the LRA. In Aviation Union of South Africa v South African Airways (Pty) Ltd 20121 SA 321 (CC) the CC confirmed that this is the correct approach to interpreting the LRA (para 34). Aviation Union of South Africa v South African Airways (Pty) Ltd 20121 SA 321 (CC) para 34

26 NEHAWU v University of Cape Town 200324 ILJ 95 (CC).

27 NEHAWU v University of Cape Town 200324 ILJ 95 (CC) paras 33-34.
} 
international labour law. ${ }^{28}$ It is for these reasons that the author has used the European Union Directives dealing with temporary service employees, fixed-term work, part-time work as well as the ILO Part-time Work Convention and Recommendations to assist with interpreting the equal pay provisions in sections 198A-198D of the LRA.

Blanpain asserts that comparative law is an excellent tool of education. He further states that by analysing foreign systems one often discovers that:

... a similar problem is resolved in another country in a completely different way, such that one cannot help but initiate the analysis and evaluation of one's own system again, but now from another angle, from an enriched point of view, from a new insight. ${ }^{29}$

The author has made extensive use of the United Kingdom's Regulations (including related materials) and case law dealing with temporary service employees, fixed-term employees as well as part-time employees to assist with interpreting the equal pay provisions in sections 198A-198D of the LRA as these Regulations were enacted to give effect to the European Union Directives concerning same. The United Kingdom's Regulations are thus an extension of the European Union Directives and is an example of what international labour law requires with regard to temporary service employees, fixed-term employees and part-time employees. It is submitted that the use of the United Kingdom's Regulations (including related materials) and the case law not only constitutes comparative labour law but also falls under the ambit of international labour law, albeit indirectly, through the prism of the European Union Directives.

\section{Equal pay for atypical employees in the United Kingdom}

\subsection{Temporary service employees}

Temporary service employees in the United Kingdom receive statutory protection for equal pay in terms of the Agency Workers Regulations, 2010 (the Agency Regulations). ${ }^{30}$ Regulation 5(1)(a) of the Agency Regulations provides that an agency worker shall be entitled to the same basic employment conditions as he would have been entitled to for doing the same work had he been recruited by the client without the intervention of a temporary work agency. Regulation 5(3) states that regulation 5(1)(a) shall be complied with if the agency worker is working under the same relevant terms and conditions as an employee who is a comparable employee. In order for an employee to qualify as a comparable employee both the agency

$28 \quad$ Valticos and Potobsky International Labour Law 49, 71-74.

$29 \quad$ Blanpain "Comparativism in Labour Law" 4.

30 Agency Workers Regulations Statutory Instrument No 93 of 2010 (the Agency Regulations). 
worker and the employee must work under the supervision and direction of the client and both must be engaged in work that is the same or broadly similar having regard to where relevant, whether they have a similar level of qualification and skills. Relevant terms and conditions of employment are terms that are ordinarily included in the contracts of employees of the client. ${ }^{31}$ Regulation 6(1) sets out the following list of terms and conditions that will fall within the meaning of "relevant terms and conditions": (a) pay; (b) duration of working time; (c) night work; (d) rest periods; (e) rest breaks; and (f) annual leave. ${ }^{32}$ Pay is further defined as any sum payable to an employee of the client in connection with the employee's employment and this includes any fee, bonus, commission, holiday pay or other emolument referable to the employment, whether payable under contract or otherwise. ${ }^{33}$

The following, inter alia, are specifically excluded from the definition of pay: (a) occupational sick pay; (b) pension payments or compensation for loss of office; (c) maternity, paternity or adoption leave payments; (d) worker's redundancy payments; (e) any payment made pursuant to a financial participation scheme; (f) bonus payments for an employee's loyalty or longterm service; (g) payment for time off for carrying out trade union activities. ${ }^{34}$ Regulation 12 provides that an agency worker has the right during an assignment to be treated no less favourably than a comparable employee with regard to collective facilities and amenities provided by the employer unless the less favourable treatment is justified on objective grounds. This includes canteen facilities, child care facilities and transport services. ${ }^{35}$

Regulation $14(1)^{36}$ provides that both the temporary work agency and the client will be liable for any breach of regulation 5 to the extent that they are responsible for the breach. An agency worker who considers that the client or the temporary work agency may have treated her in a manner that infringed a right contained in regulation 5 may lodge a written request to the temporary work agency requesting a statement in writing containing relevant information concerning the treatment in question. A temporary work agency which receives such a request must within 28 days of receipt thereof provide the agency worker with a written statement setting out the following: (a) relevant information relating to the basic employment conditions of the employees of the client; and (b) the factors that the temporary work agency took into account when determining the basic employment conditions which

\footnotetext{
31 Regulations 5(3)(b) and 5(4)(a)(i)-(ii) of the Agency Regulations.

32 Regulation 6(1)(a)-(f) of the Agency Regulations.

33 Regulation 6(2) of the Agency Regulations.

34 Regulation 6(3)(a)-(g) of the Agency Regulations.

35 Regulation 12(1)-(3)(a)-(c) of the Agency Regulations.

36 Regulation 14(1) of the Agency Regulations.
} 
applied to the agency worker at the time when the agency worker alleges that the breach of regulation 5 took place. ${ }^{37}$

The Agency Regulations gives effect to the European Council Directive on Temporary Agency Work (the EU Agency Directive). ${ }^{38}$ The purpose of the EU Agency Directive is to ensure that temporary agency workers are afforded protection and to improve the quality of their work by ensuring that the principle of equal treatment in article 5 is applied to them. ${ }^{39}$ Article $5^{40}$ provides that the basic employment conditions applying to an agency worker must be at least the same as the basic employment conditions that she would have received had she been recruited by the client to occupy the same post without the intervention of a temporary work agency. Agency workers must also be given access to the collective facilities which includes the canteen, child-care facilities and transport services under the same conditions as these are provided to the employees of the client unless the difference in treatment is justified by objective reasons. ${ }^{41}$

The BIS Guidance on the Agency Workers Regulations (the Agency Workers Guide) ${ }^{42}$ states that the meaning of equal treatment is normally a matter of common sense and the requirement is simply to treat the employee as if he had been employed directly to the same job without the intervention of a temporary work agency. It states that equal treatment is not required with regard to all the terms and conditions of employment as all that is required is that it covers the basic employment conditions. The basic employment conditions are those that are ordinarily included in the relevant contracts and set out in standard contracts, a pay scale/structure, a collective agreement and a company handbook. ${ }^{43}$ The Agency Workers Guide sets out the following example with regard to the pay scale/structure which should be applicable to an agency worker:

A hirer has various pay scales to cover its permanent workforce, including its production line. An agency worker is recruited on the production line and has several years' relevant experience. However the agency worker is paid at the bottom of the pay scale. Is this equal treatment? Yes if the hirer would have started that worker at the bottom of the pay scale if recruiting him or her directly. But if the worker's experience would mean starting further up the pay

37 Regulation 16(1)-(2)(a)-(b) of the Agency Regulations.

38 European Council Directive on Temporary Agency Work Directive 2008/104/EC (2008) (the EU Agency Directive).

39 Article 2 of the EU Agency Directive.

40 Article 5 of the EU Agency Directive.

$41 \quad$ Article 6(4) of the EU Agency Directive.

42 BIS 2011 https://www.gov.uk/government/uploads/system/uploads/attachment _data/file/32121/11-949-agency-workers-regulations-guidance.pdf (the Agency Workers Guide). The aim of this guide is to assist hirers of agency workers as well as the recruitment sector to understand the Agency Regulations. 
scale if recruited directly, then that is the entitlement. Starter grades which apply primarily, or exclusively, to agency workers may not be compliant if not applied generally to direct recruits. ${ }^{44}$

It further gives an example of where there are ten permanent employees and three agency workers doing the same work but the permanent employees are paid between $£ 8-£ 10$ per hour with recent permanent employees being paid £8 and longer serving employees earning £10. The agency workers, however, are employed on a rate of $£ 6$ per hour. The Agency Workers Guide poses the question whether this differentiation is allowed. It states that this differentiation is not allowed because there is a clear rate of at least $£ 8$ for the job and the agency workers would be entitled to this. ${ }^{45}$

\subsection{Fixed-term employees}

In the United Kingdom the Fixed-term Employees (Prevention of Less Favourable Treatment) Regulations, $2002^{46}$ (the Fixed-term Regulations) protects fixed-term employees with regard to equal pay by providing statutory protection. In terms of regulation 3(1)(a) of the Fixed-term Regulations a fixed-term employee has the right not to be treated less favourably than a comparable permanent employee of the employer with regards to the terms of her contract. It is axiomatic that pay will readily fall within the terms of a contract of employment as it is the most important term thereof. This right contained in regulation 3(1)(a) only applies if the treatment is on the ground that the employee is a fixed-term employee and it is not justified on objective grounds. ${ }^{47}$ Regulation $3(4)^{48}$ states that when determining whether a fixed-term employee has been treated less favourably than a comparable permanent employee, the pro rata principle must be applied unless it is not appropriate. The pro rata principle provides the following:

... where a comparable permanent employee receives or is entitled to pay or any other benefit, a fixed-term employee is to receive or be entitled to such proportion of that pay or other benefit as is reasonable in the circumstances having regard to the length of the contract of employment and to the terms on which the pay or benefit is offered. ${ }^{49}$

Regulation 4(1) provides that where an employer treats a fixed-term employee less favourably than a comparable permanent employee with

Agency Workers Guide 27.

Agency Workers Guide 27.

Fixed-term Employees (Prevention of Less Favourable Treatment) Regulations

Statutory Instrument No 2034 of 2002 (the Fixed-term Regulations).

47 Regulation 3(3)(a)-(b) of the Fixed-term Regulations.

48 Regulation 3(4) of the Fixed-term Regulations.

49 See the definition of the pro rata principle in reg 1 of the Fixed-term Regulations. 
regards to any terms of her contract, the treatment will be justified on objective grounds if the terms of the fixed-term employee's contract taken as a whole are at least as favourable as the terms of the comparable permanent employee's contract. Smith and Baker state that there is less likelihood of a straight pro rata solution as in the case of part-time employees as there are known mismatches between employees employed on short fixed-term contracts and long-term benefits intended for permanent employees. They state that regulation 4(1) which provides for the fixed-term employee's contract to be taken as a whole as compared to the terms of the comparator's allows the employer to rely on a package approach rather than a term-by-term approach and this will be useful where the employer pays the fixed-term employee more to reflect the fact that the employee does not qualify for longer term benefits. They remark that this package approach is unusual and is not permitted in the Part-time Workers Regulations and is also not allowed in equal pay law where the claimant can demand equality on a term-by-term basis. ${ }^{50}$

A fixed-term employee who considers that the employer treated her in a manner which infringes regulation 3 may in writing request her employer to provide her with a written statement setting out the reasons for the treatment. ${ }^{51}$ This written statement is admissible as evidence in any proceedings under the Fixed-term Regulations. An employer who deliberately omits to provide a written statement or provides a statement that is evasive or equivocal runs the risk of the tribunal drawing any inference which it considers just and equitable, including an inference that the employer infringed the right in question. ${ }^{52}$

The Fixed-term Regulations are the result of the European Union Council Directive Concerning the Framework Agreement on Fixed-term Work (the EU Fixed-term Work Directive). ${ }^{53}$ Clause 4(1) of the EU Fixed-term Work Directive states that with regard to employment conditions, fixed-term workers should not be treated less favourably than a comparable permanent worker solely because they have a fixed-term contract unless different treatment is justified on objective grounds. Clause 4(2) goes on to state that the pro rata principle will apply. ${ }^{54}$

\footnotetext{
$50 \quad$ Smith, Wood and Baker Smith and Wood's Employment Law 58 and fn 109.

51 Regulation 5(1) of the Fixed-term Regulations.

52 Regulation 5(3)(a)-(b) of the Fixed-term Regulations.

53 European Union Council Directive Concerning the Framework Agreement on Fixedterm Work Council Directive 1999/70/EC (1999) (the EU Fixed-term Work Directive); Holland, Burnett and Millington Employment Law 147; Department of Work and Pensions v Webley [2005] IRLR 288 para 13; Allen v National Group Europe Ltd [2004] IRLR 847 para 7.

$54 \quad$ Clause 4(2) of the EU Fixed-term Work Directive.
} 
The Fixed-term Work Guidance Note (the Fixed-term Guide) ${ }^{55}$ states that less favourable treatment occurs where a fixed-term employee does not get a benefit whether it is contractual or non-contractual that a comparable permanent employee receives or is offered a benefit on less favourable terms. It can also occur if the employer fails to do something for a fixed-term employee that he does for a permanent employee. The Fixed-term Guide also states that a fixed-term employee can also be less favourably treated than a comparator even if their contracts are the same but the permanent employee is given benefits which are not given to the fixed-term employee. This non-contractual benefit can be a bonus. Employers may take two approaches to ensuring equal treatment for fixed-term employees namely: the term-by-term approach or the package approach. ${ }^{56}$

The term-by-term approach means that every individual term of a fixed-term employee's employment package should be exactly the same or on a pro rata basis as that of the comparable permanent employee unless a difference in the term is objectively justified. For example, if a permanent employee is paid $£ 350$ per week and has 25 days' annual leave per year, the same conditions should apply to a fixed-term employee unless objectively justified. The package approach is where the employer balances a less favourable condition against a more favourable one on condition that he ensures that a fixed-term employee's overall employment package is not less favourable than the employment package of the permanent employee. The employer will not be prevented from paying higher up-front rewards in return for reduced benefits elsewhere if the fixed-term employee's overall package is not less favourable. The benefits should be valued on the basis of their objective worth. The employer is allowed to justify not providing the fixed-term employee with a particular benefit if he chooses a package approach. ${ }^{57}$ The Fixed-term Guide sets out the following example with regard to the package approach:

Example of using the package approach: A fixed-term employee is paid $£ 20,800$ per year ( $£ 400$ per week) which is the same as a comparable permanent employee but gets three days' fewer paid holiday per year than comparable permanent employees. To ensure that the fixed-term employee's overall employment package is not less favourable, their annual salary is

$55 \quad$ This guidance note sets out the requirements of the Fixed-term Regulations and its purpose is to explain the requirements of the Regulations to employers, union representatives and employees. National Archives 2007 http://webarchive.nationalarchives.gov.uk/20070603164510/http://www.dti.gov.uk/e mployment/employment-legislation/employment-guidance/page18475.html.

56 National Archives 2007 http://webarchive.nationalarchives.gov.uk/ 20070603164510/http://www.dti.gov.uk/employment/employmentlegislation/employment-guidance/page18475.html.

57 National Archives 2007 http://webarchive.nationalarchives.gov.uk/ 20070603164510/http://www.dti.gov.uk/employment/employmentlegislation/employment-guidance/page18475.html. 
increased to $£ 20,970$. ( $£ 170$ is added on, since this is the value of three days' holiday pay. A day's holiday pay is worked out as annual salary divided by 365. $)^{58}$

It is clear that the test to determine whether a fixed-term employee has been treated less favourably according to the package approach is not a test which requires that a fixed-term employee must be treated exactly the same as a comparable permanent employee. The package approach looks at whether on the whole the fixed-term employee is treated less favourably. This takes into account the realities of the employment relationship and is a realistic approach to a complex analysis. The test which is used is the pro rata principle unless it is inappropriate. The pro rata principle provides that a fixed-term employee is entitled to receive such proportion of the pay and benefits provided to the comparable permanent employee as is reasonable in the circumstances having regard to the length of the fixed-term employee's contract and the terms on which the pay or benefit is offered. If the pro rata test has been satisfied then the fixed-term employee has not been treated less favourably than a comparable full-time employee. Even where a fixed-term employee is treated less favourably than a comparable permanent employee then this treatment can still be justified on objective grounds if the terms of the fixed-term employee's contract taken as a whole are at least as favourable as the terms of the comparable permanent employee's contract of employment. This test takes a realistic approach to achieving equal pay for fixed-term employees and undertakes the comparison of the terms and conditions of employment within a framework specifically designed for achieving equal pay for fixed-term employees which is by no means an easy task.

In Department of Work and Pensions $v$ Webley 59 the England and Wales Court of Appeal held that the non-renewal of a fixed-term contract does not constitute less favourable treatment within the meaning of the Fixed-term Regulations. ${ }^{60}$ In Allen $v$ National Group Europe Ltd ${ }^{61}$ the Employment Appeal Tribunal held that the existence of a provision in a fixed-term contract which allows it to be terminated earlier by notice does not deny the worker the protection of the Fixed-Term Regulations. ${ }^{62}$

\footnotetext{
58 National Archives $2007 \quad$ http://webarchive.nationalarchives.gov.uk/ 20070603164510/http://www.dti.gov.uk/employment/employmentlegislation/employment-guidance/page18475.html.

59 Department of Work and Pensions v Webley [2005] IRLR 288.

60 Department of Work and Pensions $v$ Webley [2005] IRLR 288 paras 43-45.

$61 \quad$ Allen v National Group Europe Ltd [2004] IRLR 847.

62 Allen v National Group Europe Ltd [2004] IRLR 847 para 32.
} 


\subsection{Part-time employees}

The ILO Part-time Work Convention states that member states must take measures to ensure that part-time workers do not receive, because they work part-time, a basic wage which is lower than the basic wage of comparable full-time workers. ${ }^{63}$ The ILO Part-time Work Recommendation provides that part-time workers should "... benefit on an equitable basis from financial compensation, additional to basic wages, which is received by comparable full-time workers". ${ }^{64}$

In the United Kingdom, part-time workers receive statutory protection for equal pay in terms of the Part-time Workers (Prevention of Less Favourable Treament) Regulations, $2000^{65}$ (the Part-time Regulations). As the Parttime Regulations only applies to part-time workers it is important to know which workers qualify as part-time workers. Regulation 2(2) ${ }^{66}$ defines a parttime worker as a worker who is paid wholly or in part by reference to the time she works and having regard to the custom and practice of the employer in relation to workers employed under the same type of contract. It further states that a part-time worker is a worker that is not identifiable as a full-time worker. ${ }^{67}$ In terms of the Part-time Regulations a part-time worker has the right not be treated by her employer less favourably than her employer treats a comparable full-time worker regarding the terms of her contract. ${ }^{68}$ This right only applies if the less favourable treatment is on the ground that the worker is a part-time worker and the treatment is not justified on objective grounds. ${ }^{69}$ The Guidance Notes to the Part-time Regulations provides that less favourable treatment will only be justified on objective grounds if it can be shown that the less favourable treatment:

(1) is to achieve a legitimate objective, for example, a genuine business objective;

(2) is necessary to achieve that objective; and

(3) is an appropriate way to achieve the objective..$^{70}$

\footnotetext{
$63 \quad$ Article 5 of the ILO Part-time Work Convention No 175 (1994).

64 Item 10 of the ILO Part-time Work Recommendation No 182 (1994).

65 Part-time Workers (Prevention of Less Favourable Treament) Regulations Statutory Instrument No 1551 of 2000 (the Part-time Regulations). Duggan Equal Pay 242 states that the Part-time Regulations are not gender based and as such provides and easier route for the part-time worker than claims in equal pay where the principles are complex.

66 Regulation 2(2) of the Part-time Regulations.

67 Regulation 2(2) of the Part-time Regulations.

68 Regulation 5(1)(a) of the Part-time Regulations.

69 Regulations 5(2)(a)-(b) of the Part-time Regulations.

70 National Archives 2000 http://www.legislation.gov.uk/uksi/2000/1551/note/made.
} 
Regulation $5(3)^{71}$ states that in determining whether a part-time worker has been treated less favourably than a comparable full-time worker the pro rata principle must be applied unless it is inappropriate. The pro rata principle provides the following:

... where a comparable full-time worker receives or is entitled to receive pay or any other benefit, a part-time worker is to receive or be entitled to receive not less than the proportion of that pay or other benefit that the number of his weekly hours bears to the number of weekly hours of the comparable full-time worker. ${ }^{72}$

In terms of this pro rata test a part-time employee is not treated less favourably than a comparable full-time worker if he receives the proportion of pay and benefits that the number of his weekly hours bears to the number of weekly hours of the comparable full-time worker. This test is specifically designed to achieve equal pay for part-time workers and it thus different from the pro rata test used in the case of fixed-term contract employees. The Guidance Notes to the Part-time Regulations provides that the Parttime Regulations has a direct effect on pay and as a result thereof part-time workers should not receive a lower basic rate of pay than comparable fulltime workers. It further provides that a part-time worker can only be given a lower hourly rate if it is justified on objective grounds and in this regard it states that an example of when a lower hourly rate will be justified is a performance related pay scheme. It further provides that in order to comply with the law, part-time workers should receive the same hourly rate as comparable full-time workers. ${ }^{73}$

Regulation $5(4)^{74}$ states that a part-time worker who is paid at a lower rate for overtime worked than a comparable full-time worker would be paid for overtime worked in the same period shall not for that reason be regarded as being treated less favourably than the comparable full-time worker where the total number of hours worked by the part-time worker including the overtime, does not exceed the number of hours the comparable full-time worker is required to work in the period. The Guidance Notes to the Parttime Regulations provides that part-time workers "... should receive the same hourly rate of overtime pay as comparable full-time workers, at least once they have worked more than the normal full-time hours". ${ }^{75}$

The Part-time Regulations importantly, contains a provision which allows a worker who considers that her employer may have treated her in a manner that infringes her rights in terms of regulation 5 to request from her employer

Regulation 5(3) of the Part-time Regulations.

Regulation 1 of the Part-time Regulations.

National Archives 2000 http://www.legislation.gov.uk/uksi/2000/1551/note/made.

Regulation 5(4) of the Part-time Regulations.

National Archives 2000 http://www.legislation.gov.uk/uksi/2000/1551/note/made. 
a written statement setting out the reasons for the treatment. ${ }^{76}$ This written statement is admissible as evidence in any proceedings under these regulations. If a tribunal finds, in any proceedings, that the employer deliberately, and without reasonable excuse, omitted to provide a written statement or that the written statement is evasive or equivocal then it may draw an inference which it considers just and equitable including an inference that the employer has infringed the worker's right in question. ${ }^{77}$

It is important to note that regulation 2 sets out the comparator and the scope of the claim. It states that a full-time worker is a comparable full-time worker if at the time when the treatment that is alleged to be less favourable takes place, both the comparable full-time worker and the part-time worker are employed by the same employer under the same type of contract and engaged in the same or broadly similar work having regard to where relevant, the level of qualification, skills and experience. It further states that the full-time worker must be based at the same establishment as the parttime worker or where there is no full-time worker at the same establishment then a comparison with a full-time worker at a different establishment will suffice. ${ }^{78}$

The Part-time Work Best Practice Guide ${ }^{79}$ (the Part-time Work Guide) states that part-time workers should receive the same basic rate of pay as compared to comparable full-time workers unless it is justified by objective grounds. A different hourly rate might be objectively justified where a performance related pay scheme is used. 80 The Part-time Work Guide sets out the following examples regarding the entitlement of part-time workers receiving the same hourly rate as comparable full-time workers:

Bonus pay: A firm awards its workers a Christmas bonus. Its part-time workers receive a pro rata amount, depending on the number of hours they work.

Shift allowances: A store has both full-time and part-time workers, working early, day and late shifts. The early and late shifts attract time-and-a-half pay for both full-time workers and comparable part-time workers.

\footnotetext{
76 Regulation 6(1) of the Part-time Regulations.

77 Regulation 6(2)-(3)(a)-(b) of the Part-time Regulations.

78 Regulation 2(4)(a)-(b) of the Part-time Regulations.

79 National Archives 2010 http://webarchive.nationalarchives.gov.uk/+/berr.gov.uk/ whatwedo/employment/employment-legislation/employmentguidance/page19479.html. whatwedo/employment/employment-legislation/employmentguidance/page19479.html.
} 
Unsocial hours: A part-time care assistant receives the same unsocial hours payment for working between midnight and 6 am as his comparable full-time colleague. ${ }^{81}$

The Part-time Regulations gives effect to the European Council Directive Concerning the Framework Agreement on Part-time Work (EU Part-time Work Directive). ${ }^{82}$ The purpose of the EU Part-time Work Directive is to remove discrimination against part-time workers and improve the quality of their work. ${ }^{83}$ Clause 4 states that with regard to employment conditions, part-time workers should not be treated in a less favourable manner than comparable full-time workers for the sole reason that they work part-time unless different treatment is justified on objective grounds. ${ }^{84}$ The pro rata principle also applies where appropriate..$^{85}$

In McMenemy $v$ Capita Business Services $L t d^{86}$ the appellant who worked Wednesdays, Thursdays and Fridays claimed that he was being treated less favourably than comparable full-time workers as he did not receive the benefit of public holidays which fell on Mondays. The Employment Tribunal held that there had been no contravention of the Part-time Regulations and that the distinction was not between full-time and part-time workers but between those who work on Mondays and those who do not, irrespective of whether they were full-time. It further held that this would have been clear if there existed a full-time employee who did not work on Mondays. ${ }^{87}$ The Employment Appeal Tribunal upheld the decision of the Employment Tribunal and held that the pro rata principle referred to in regulation 5(3) of the Part-time Regulations only related to the question of whether or not a part-time worker had received less favourable treatment than a full-time worker. It further held that this principle is not stated as an independent right and did not apply at the stage when considering whether or not the less favourable treatment was on the ground that the employee was a part-time worker. ${ }^{88}$

The Court of Session stated that it was common cause that the appropriate comparators were the full-time workers in the appellant's team who worked Mondays to Fridays and that by comparison with them the appellant received less favourable treatment because by working Wednesdays,

81 National Archives 2010 http://webarchive.nationalarchives.gov.uk/+/berr.gov.uk/ whatwedo/employment/employment-legislation/employmentguidance/page19479.html. European Council Directive Concerning the Framework Agreement on Part-time Work Council Directive 97/81/EC (1997) (the EU Part-time Work Directive). Clause 1(a) of the EU Part-time Work Directive.

Clause 4 of the EU Part-time Work Directive. Clause 4(2) of the EU Part-time Work Directive. McMenemy v Capita Business Services Ltd [2007] IRLR 400. McMenemy v Capita Business Services Ltd [2007] IRLR 400 paras 9, 13. McMenemy v Capita Business Services Ltd [2007] IRLR 400 para 10. 
Thursdays and Fridays he did not receive the benefit of any statutory holidays which fell on Mondays. The Court remarked that he did, however, receive the benefit of any statutory holiday that fell on a Wednesday, Thursday or a Friday. The Court held that it is at this stage that the pro rata principle applies. It then moved to the next question which was whether the less favourable treatment was solely because the appellant was a part-time worker and in this regard it stated that the intention of the respondent must be examined. The Court stated that the reason for the appellant receiving less favourable treatment than a comparable full-time worker was due to an agreement with the respondent that he would not work for them on Mondays or Tuesdays. It stated that at this point it becomes legitimate to consider hypothetical situations in order to test the true intention of the respondent. The Court held that based on the respondent's policy on public holidays, if a full-time worker of the appellant's team worked a fixed shift from Tuesday to Saturday then such worker would not receive the benefit of statutory holidays which fell on Mondays and if the appellant or any other part-time member of his team worked on Mondays then they would receive the benefit of the statutory Monday holidays in precisely the same way as full-time employees would. The Court consequently dismissed the appeal. ${ }^{89}$

In Sharma v Manchester City Councipo the Employment Appeal Tribunal held that the basic framework of the Part-time Regulations is for the claimant to identify a comparable full-time worker, establish less favourable treatment and satisfy the Tribunal that the less favourable treatment is on the ground that the claimant is a part-time worker. Once this has been established then the onus shifts to the employer to prove that there is an objectively justifiable reason for the less favourable treatment. It further held that once it is found that the part-time worker is treated less favourably than a comparable fulltime worker and the worker's part-time status is one of the reasons, then this will be sufficient to trigger the protection offered in the Part-time Regulations.

\section{Conclusion and recommendations}

The equal pay legal framework in the LRA in the form of sections 198A(5), $198 B(8)(a)$ and $198 C(3)$ (a) is unique to the law regulating equal pay in South Africa. The sections only apply to atypical employees provided they earn below the prescribed threshold and subject to certain other conditions. The LRA equal pay legal framework is thus of limited application and does not apply to all atypical employees. The framework is not easy to understand especially within the matrix of equal pay law. The references to "on the whole not less favourably" and "not less favourably" presents

89 McMenemy v Capita Business Services Ltd [2007] IRLR 400 paras 13-14.

90 Sharma v Manchester City Council [2008] IRLR 336. 
challenges with regard to what the sections require. These phrases have not come under scrutiny before our labour courts and no test has been formulated in this regard.

The United Kingdom has a comprehensive equal pay legal framework for atypical employees. This legal framework is as a result of European Directives on the subject. The equal pay framework for atypical employees in the United Kingdom explains how equal pay is to be achieved for atypical employees by setting out how same must be tested. There are Guides which have been published to assist in the interpretation of the equal pay legal framework. The comparative study with the equal pay legal framework relating to atypical employees in the United Kingdom is important as it allows for lessons to be learnt for the South African equal pay legal framework in the LRA relating to atypical employees which is in its infancy. Based on the above analysis, the author will attempt to explain what is required from the equal pay legal framework in the LRA relating to atypical employees by making submissions and recommendations and the law regulating same in the United Kingdom will be referred to.

\subsection{Equal pay for part-time employees in terms of section 198C(3)(a) of the LRA}

Section $198 \mathrm{C}(3)$ (a) of the LRA states that an employer must treat a parttime employee on the whole not less favourably as compared to a comparable full-time employee performing the same or similar work taking the part-time employee's working hours into account irrespective of when she was employed unless there is a justifiable reason for the differential treatment. This is the crux of the cause of action for part-time employees seeking equal pay. No further explanation of the section is provided in the Memo. Regulation 5(1)(a) of the Part-time Regulations states that a parttime worker must not be treated less favourably than a comparable full-time employee. In order to test whether a part-time worker has been treated less favourably the pro rata principle is used. ${ }^{91}$ The pro rata principle in respect of part-time workers provides that where a comparable full-time worker receives or is entitled to receive pay or any other benefit then a part-time worker must receive or must be entitled to receive not less than the proportion of that pay or benefit in relation to the number of his weekly hours as compared to the weekly hours of the comparable full-time worker. The Guidance Notes to the Part-time Regulations states that a part-time worker should not receive a lower hourly rate unless it can be justified on objective grounds for example, a lower hourly rate will be justified if a performance related pay scheme is used.

91 Regulation 5(3) of the Part-time Regulations. 
It is clear that the nub of the Part-time Regulations is that the employer must give the part-time employee a pro rata portion of the wages and benefits as received by a comparable full-time worker according to the hours worked by the part-time employee. It is submitted that the pro rata principle should be used as the test for determining an equal pay dispute involving a part-time employee in terms of section $198 \mathrm{C}(3)$ (a) of the LRA. It is further submitted that the pro rata principle is a test which is specifically designed to achieve equal pay for part-time workers and it takes into account the realities of the employment relationship whilst protecting the part-time employee's equal pay rights. It is lastly submitted that the pro rata principle will bring about results which will give a proper and contextual meaning to the phrase "on the whole not less favourably" as used in section 198C(3)(a) of the LRA.

\subsection{Equal pay for fixed-term employees in terms of section 198B(8)(a) of the LRA}

Section $198 \mathrm{~B}(8)(\mathrm{a})$ of the LRA states that an employer must not treat an employee employed on a fixed-term contract for longer than three months less favourably than a comparable full-time employee performing the same or similar work unless there is a justifiable reason for the different treatment. The Memo states that a fixed-term contract employee employed for longer than three months must be treated on the whole not less favourably than a comparable full-time employee performing the same or similar work. There seems to be a contradiction between the section and the Memo as the section states that the employee must not be treated less favourably whereas the Memo states that the employee must not be treated on the whole less favourably. There is no explanation for the difference in this regard and this is the crux of the cause of action regarding equal pay for fixed-term employees as set out in section 198B(8)(a) of the LRA.

Regulation 3(1)(a) of the Fixed-term Regulations states that a fixed-term employee has the right not to be treated less favourably than a comparable full-time employee. The pro rata principle is used to test whether the fixedterm employee has been treated less favourably than a comparable full-time employee. The application of the pro rata principle is subject to the principle being appropriate in the particular circumstances. The pro rata principle in respect of a fixed-term employee provides that where a comparable full-time employee receives or is entitled to receive pay or any other benefit then a fixed-term employee must receive or must be entitled to receive such proportion of that pay or benefit as is reasonable in the circumstances having regard to the length of the contract and to the terms on which the pay or benefit is offered. The Fixed-term Regulations goes further and states that where an employer treats a fixed-term employee less favourably than a comparable full-time employee with regards to any terms of his 
contract then the treatment will be justified on objective grounds if the fixedterm employee's contract taken as a whole are at least as favourable as the terms of the comparable permanent employee's contract.

The phrase not to be treated less favourably in regulation 3(1)(a) of the Fixed-term Regulations is intended to bring about equal pay for the fixedterm employee which is the same according to the pro rata principle or which is on the whole not less favourable than that of a comparable full-time employee. The Fixed-term Guide states that employers may take two approaches to comply with the equal pay requirements of regulation 3(1)(a) of the Fixed-term Regulations. The first approach is the term-by-term approach and the second approach is the package approach. The term-byterm approach requires that every individual term of a fixed-term employee's employment package must be exactly the same or on a pro rata basis to that of a comparable permanent employee unless the differentiation can be justified objectively. It is submitted that this approach is required in terms of the pro rata principle. The package approach is where the employer balances a less favourable condition against a more favourable condition provided that a fixed-term employee's overall employment package is not less favourable than the employment package of a comparable full-time employee. The employer can do this by paying higher up-front rewards in return for reduced benefits elsewhere provided that the fixed-term employee's overall package is not less favourable. The benefits should be valued on the basis of their objective worth. This means that an employer can justify not providing the fixed-term employee with a particular benefit if he chooses to use the package approach. It is submitted that this approach accords with the on the whole not less favourable approach.

Smith and Baker state that there is less likelihood of a straight pro rata solution as in the case of part-time employees as there are known mismatches between employees employed on short fixed-term contracts and long-term benefits intended for permanent employees. They, however, state that the package approach is not allowed in equal pay law where the claimant is entitled to demand equality on a term-by-term basis. It is submitted that the pro rata principle test (term-by-term approach) and the on the whole not less favourable approach (package approach) should be used as the tests for determining equal pay disputes involving fixed-term employees in terms of section 198B(8)(a) of the LRA. It is further submitted that the package approach should only be used if the pro rata principle test cannot be applied for inappropriateness. This submission is based on the fact that equal pay law requires equality on a term-by-term basis. It is also based on the recognition that a term-by-term approach will not be able to be applied to each and every fixed-term employee's case and this is when the package approach should be used. It is lastly submitted that an 
employer who uses the package approach will have to provide objective reasons as to why the term-by-term approach is inappropriate when called upon to provide justification for the differential treatment in terms of section $198 B(8)(a)$ read with section $198 D(2)$ of the LRA.

\subsection{Equal pay for deemed employees in terms of section 198A(5) of the LRA}

Section $198 \mathrm{~A}(5)$ of the LRA states that a temporary service employee who is deemed to be an employee of the client must be treated on the whole not less favourably as compared to a comparable employee of the client performing the same or similar work unless there is a justifiable reason. Section $198 \mathrm{~A}(3)(\mathrm{b})(\mathrm{ii})$ of the LRA provides that a temporary service employee is deemed to be the employee of the client and employed on an indefinite basis by the client subject to the provisions of section 198B of the LRA which deals with fixed-term contract employees who earn below the threshold. This would mean that a temporary service employee may be deemed to be an employee of the client and employed on an indefinite basis or on a fixed-term contract basis, whichever is applicable in the circumstances.

Regulations 5(1)(a) of the Agency Regulations states that an agency worker must be entitled to the same basic employment conditions that she would have been entitled to had she been recruited by the client without the intervention of the temporary work agency. The Agency Regulations states that regulation 5(1)(a) will be met if the temporary worker receives the same relevant terms and conditions as the comparable employee of the client. The Regulations further sets out terms and conditions that will fall within the ambit of relevant terms and conditions. The Regulations further state that both the temporary work agency and the client will be liable for any breach of regulation 5 to the extent that they are responsible for the breach. The Agency Regulations does not refer to the pro rata principle test (term-byterm approach) or the on the whole not less favourable test (package approach).

It is, however, submitted that the term-by-term approach and the package approach should be used when deciding an equal pay dispute relating to a temporary service employee who is deemed to be an employee of the client. It is submitted that if the temporary service employee is deemed to be an employee of the client on an indefinite basis then the term-by-term approach (pro rata principle test) should apply to such employee. It is further submitted that if the temporary service employee is deemed to be an employee of the client on a fixed-term contractual basis then the term-byterm approach should be applied, unless it is inappropriate in the circumstances, in which case, the package approach should apply to such 
employee. It is lastly submitted that the application of these approaches takes into account the realities of the employment relationship whilst at the same time giving effect to the equal pay provision in section 198A(5) of the LRA.

\section{Bibliography}

\section{Literature}

Benjamin Agency Work

Benjamin P Law and Practice of Private Employment Agency Work in South Africa (International Labour Office Geneva 2013)

Blanpain "Comparativism in Labour Law"

Blanpain R "Comparativism in Labour Law and Industrial Relations" in Blanpain R (ed) Comparative Labour Law and Industrial Relations in Industrialized Market Economies (Kluwer Law International Alphen-aanden-Rijn 2004) 3-24

Duggan Equal Pay

Duggan M Equal Pay: Law and Practice (Jordan Bristol 2009)

Fourie 2008 PELJ

Fourie ES "Non-standard Workers: The South African Context, International Law and Regulation by the European Union" 2008 PELJ 110-184

Grogan Workplace Law

Grogan J Workplace Law $10^{\text {th }}$ ed (Juta Cape Town 2009)

Holland, Burnett and Millington Employment Law

Holland J, Burnett S and Millington P Employment Law (Oxford University Press Oxford 2015)

Smith, Wood and Baker Smith and Wood's Employment Law

Smith IT, Wood JC and Baker A Smith \& Wood's Employment Law $11^{\text {th }}$ ed (Oxford University Press Oxford 2013)

Theron 2005 ILJ

Theron $\mathrm{J}$ "Intermediary or Employer? Labour Brokers and the Triangular Employment Relationship" 2005 ILJ 618-649

Valticos and Potobsky International Labour Law

Valticos N and Potobsky G International Labour Law $2^{\text {nd }}$ ed (Kluwer Law and Taxation Deventer 1995) 
Van Eck 2010 PELJ

Van Eck BPS "Temporary Employment Services (Labour Brokers) in South Africa and Namibia" 2010 PELJ 107-126

\section{Case law}

\section{South Africa}

Aviation Union of South Africa v South African Airways (Pty) Ltd 20121 SA 321 (CC)

NEHAWU v University of Cape Town 200324 ILJ 95 (CC)

National Union of Metalworkers of South Africa v Driveline 20004 SA 645 (LAC)

Shoprite Checkers (Pty) Ltd v Ramdaw 20013 SA 68 (LC)

\section{United Kingdom}

Allen v National Group Europe Ltd [2004] IRLR 847

Department of Work and Pensions v Webley [2005] IRLR 288

McMenemy v Capita Business Services Ltd [2007] IRLR 400

Sharma v Manchester City Council [2008] IRLR 336

\section{Legislation}

\section{South Africa}

Constitution of the Republic of South Africa, 1996

Employment Equity Act 55 of 1998

Labour Relations Act 66 of 1995

\section{United Kingdom}

Agency Workers Regulations Statutory Instrument No 93 of 2010

Fixed-term Employees (Prevention of Less Favourable Treatment) Regulations Statutory Instrument No 2034 of 2002

Part-time Workers (Prevention of Less Favourable Treament) Regulations Statutory Instrument No 1551 of 2000 


\section{International and regional instruments}

European Council Directive Concerning the Framework Agreement on Parttime Work Council Directive 97/81/EC (1997)

European Council Directive on Temporary Agency Work Directive 2008/104/EC (2008)

European Union Council Directive Concerning the Framework Agreement on Fixed-term Work Council Directive 1999/70/EC (1999)

ILO Part-time Work Convention No 175 (1994)

ILO Part-time Work Recommendation No 182 (1994)

\section{Internet sources}

BIS 2011 https://www.gov.uk/government/uploads/system/uploads/attachment_data/file/32121/11-949-agency-workers-regulations-guidance.pdf Department for Business Innovation and Skills 2011 Guidance on the Agency Workers Regulations https://www.gov.uk/government/uploads/ system/uploads/attachment_data/file/32121/11-949-agency-workersregulations-guidance.pdf accessed 16 February 2017

DoL 2013 http://www.labour.gov.za/DOL/downloads/legislation/bills/pro posed-amendment-bills/lraamendmentbill2013.pdf

Department of Labour 2013 Memorandum of Objects of the Labour Relations Amendment Bill, 2012 http://www.labour.gov.za/ DOL/downloads/legislation/bills/proposed-amendmentbills//raamendmentbill2013.pdf accessed 15 February 2017

National Archives 2000 http://www.legislation.gov.uk/uksi/2000/1551/ note/made

National Archives 2000 Guidance Notes to the Part-time Regulations http://www.legislation.gov.uk/uksi/2000/1551/note/made accessed on 15 February 17

National Archives 2007 http://webarchive.nationalarchives.gov.uk/2007 0603164510/http://www.dti.gov.uk/employment/employment-

legislation/employment-guidance/page18475.html

National Archives 2007 Fixed-Term Work Guidance Note http://webarchive.nationalarchives.gov.uk/20070603164510/http://www.dti. gov.uk/employment/employment-legislation/employmentguidance/page18475.html accessed on 16 February 2017 
National Archives 2010 http://webarchive.nationalarchives.gov.uk/+ /berr.gov.uk/whatwedo/employment/employment-legislation/employmentguidance/page19479.html National Archives 2010 Part-time Workers: The Law and Best Practice - A Detailed Guide for Employers and Part-timers http://web archive.nationalarchives.gov.uk/+/berr.gov.uk/whatwedo/employment/empl oyment-legislation/employment-guidance/page19479.html accessed 17 February 2017

\section{List of Abbreviations}

BIS

CCMA

DoL

EEA

ILJ

ILO

LRA

PELJ
Department for Business Innovation and Skills

Commission for Conciliation, Mediation and Arbitration

Department of Labour

Employment Equity Act 55 of 1998

Industrial Law Journal

International Labour Organisation

Labour Relations Act 66 of 1995

Potchefstroom Electronic Law Journal 